\title{
RESEARCH ON ENZYME INHIBITION POTENTIAL AND PHENOLIC COMPOUNDS FROM ORIGANUM VULGARE SSP. VULGARE
}

\author{
DANIELA HANGANU ${ }^{1, \#}$, DANIELA BENEDEC ${ }^{1 *}$, NELI-KINGA OLAH ${ }^{2}$, FLORICA RANGA $^{3}$, \\ SIMONA MIREL ${ }^{1, *}$, BRÎNDUSSA TIPERCIUC $^{1, \#,}$, ILIOARA ONIGA ${ }^{1}$ \\ 1 “Iuliu Haţieganu” University of Medicine and Pharmacy, 8 V. Babeș Street, RO-400010, Cluj-Napoca, Romania \\ 2 "Vasile Goldiş" Western University of Arad, 94 Revoluției Avenue, Arad, Romania \\ ${ }^{3}$ University of Agricultural Science and Veterinary Medicine, 3-5 Mănăștur Street, Cluj-Napoca, Romania
}

*corresponding author: dani_67ro@yahoo.com

${ }^{\#}$ Authors with equal contribution

Manuscript received: December 2019

\begin{abstract}
This study assessed for the first time, the enzyme inhibitory properties of the Origanum vulgare ssp. vulgare extract. The main compounds were analysed chromatographically and spectrophotometrically. The enzymatic inhibitory potential was evaluated in vitro, against enzymes that play key roles in different diseases: acetylcholinesterase, urease, tyrosinase, trypsin and xanthine oxidase. A specific phenolic profile was evidenced, with large amounts of rosmarinic acid and luteolin 7-Oglucuronide; two phenolic diterpenes (rosmanol and rosmadial) were identified for the first time in this species. The oregano extract exhibited significant urease, tyrosinase and xanthine oxidase inhibitory effects, in line with the phenolic content. As a result of this study, new potential biological activities have been described for Origanum vulgare extract, which can be further studied and used in the pharmaceutical field.
\end{abstract}

\section{Rezumat}

În acest studiu se evaluează pentru prima dată potenţialul inhibitor enzimatic al extractului de Origanum vulgare ssp. vulgare (şovârf). Principalii compuşi chimici au fost analizaţi prin metode cromatografice şi spectrofotometrice. Capacitatea inhibitorie a fost evaluată in vitro, asupra unor enzime implicate în anumite afecţiuni: acetilcolinesteraza, ureaza, tirozinaza, tripsina şi xantin-oxidaza. În ceea ce priveşte profilul fenolic al extractului, s-au pus în evidenţă cantităţi mari de acid rozmarinic şi luteolin-7-O-glucuronidă; două diterpene fenolice (rosmanol şi rosmadial) au fost identificate pentru prima dată în această specie. Extractul de șovârf a inhibat semnificativ ureaza, tirozinaza și xantin-oxidaza, în concordanță cu conținutul mare de compuşi polifenolici. Prin acest studiu s-au semnalat noi activităţi biologice potenţiale ale extractului de Origanum vulgare, care deschid noi perspective de interes ştiinţific în domeniul farmaceutic.

Keywords: Origanum vulgare ssp. vulgare, polyphenols, enzyme inhibition

\section{Introduction}

Origanum vulgare L. (Lamiaceae family) is used worldwide for its flavour as a spice, having a long history of use in gastronomy and traditional medicine $[10,28]$. At the same time, oregano is considered a medicinal plant due to its complex chemical composition which includes: essential oil, polyphenols, diterpenoids, triperpenoids. It is known as antimicrobial, antiviral, hepatoprotective, antidiabetic, antiinflammatory, antioxidant, antispasmodic, antiurolithic, antiproliferative, neuroprotective agent, to mention some of the scientifically proven therapeutic actions $[6-8,11,23$, $25,26]$. Natural herbal products are increasingly used in many fields: pharmaceutical, food and cosmetics. In recent years, interest in this plant, as well as the enzymatic activities of plant extracts involved in the protection of human health, have increased. The purpose of this study was to analyse the chemical composition and to evaluate the enzymatic inhibition of $O$. vulgare ssp. vulgaris ethanolic extract, in order to be used in the design of new formulations with therapeutic applications in Alzheimer's disease, ulcer, gout, or hyperpigmentation.

\section{Materials and Methods}

The aerial parts of $O$. vulgare ssp. vulgare were harvested from Beliş (Cluj, Romania), during the blooming period (July 2018) and a voucher specimen (no. 96) was deposited in the Herbarium of the Department of Pharmacognosy, Faculty of Pharmacy, Cluj-Napoca, Romania. The extract was prepared in $70 \%$ vol. ethanol and the ratio between the vegetal material and the solvent was $1: 10(\mathrm{~m} / \mathrm{v})[2,5,32]$.

Chemicals, HPLC chromatographic conditions and quantitative analysis

Chemicals were obtained from Merck, Alfa-Aesar and Roth (Germany). 
The HPLC analysis was performed using an Agilent HPLC system series 1200 with quaternary pump, solvent degassing system, auto-sampler, DAD spectrophotometric detector and single quadruple MS detector type Agilent 6110 (Agilent Technologies, CA, USA). The separation was performed on an Eclipse XDB C18 column, $4.6 \times 150 \mathrm{~mm}$ with particles of $5 \mu \mathrm{m}$ (Agilent Technologies, USA), at $25^{\circ} \mathrm{C}$, in gradient elution. The mobile phases were water: $0.1 \%$ acetic acid in acetonitrile (99:1) (solvent $\mathrm{A}$ ) and $0.1 \%$ acetic acid in acetonitrile (solvent B) at a flow of $0.5 \mathrm{~mL} /$ min. The gradient applied was as follows: $\% \mathrm{~B}=5 \%$ (0 - $2 \mathrm{~min}$ ), from $5 \%$ to $40 \%$ (2 - $18 \mathrm{~min}$ ), from $40 \%$ to $90 \%$ (18 - $20 \mathrm{~min})$, then isocratic $4 \mathrm{~min}$ and decrease from $90 \%$ to $5 \%$ (24 - $25 \mathrm{~min}$ ). The MS was used in ESI positive mode, in the following scanning conditions: capillary voltage at $3.000 \mathrm{~V}$, temperature at $300^{\circ} \mathrm{C}$, nitrogen flow at $8 \mathrm{~L} / \mathrm{min}, \mathrm{m} / \mathrm{z}$ ranges from 100 to 1000 , full-scan mode. The DAD spectrophotometric detection was performed at $340 \mathrm{~nm}$. The data acquisition and the results processing were performed using ChemStation software from Agilent Technologies, USA. The identification was performed by comparison of obtained MS spectra with the ones from the library, meanwhile for the quantitative determination was used the DAD detection [3].

Determination of total polyphenols content

The total polyphenols content (TPC) was determined using the Folin-Ciocalteu method, with a calibration curve of gallic acid $\left(\mathrm{R}^{2}=0.999\right)$, and the results were expressed as mg of gallic acid equivalents (GAE)/g dry plant material $[2,4,14,32]$.

Enzyme inhibitory activity

Urease inhibition assay. This assay is based on ammonia quantification after urea hydrolysis in the presence of urease. Briefly, $0.2 \mathrm{~mL}$ urease $(0.1 \mathrm{mg} /$ $\mathrm{mL})$ were treated with $4 \mathrm{~mL}$ Tris- $\mathrm{HCl}$ acid buffer $(\mathrm{pH} 8), 0.2 \mathrm{~mL}$ urea $(60 \mathrm{mM})$ and $0.02 \mathrm{~mL}$ extract. The mixture was incubated at $30^{\circ} \mathrm{C}$, for $20 \mathrm{~min}$ and then the reaction was stopped by addition of $1 \mathrm{~mL}$ $10 \%$ trichloroacetic acid. The ammonia content was evaluated by using $0.5 \mathrm{~mL}$ Nessler reagent. Absorbance was determined at $436 \mathrm{~nm}$. Thiourea $(200 \mu \mathrm{g} / \mathrm{mL})$ was used as a standard inhibitor [24].

Tyrosinase inhibition assay. The activity of this enzyme was spectrometrically evaluated using L-DOPA as a substrate. To $0.4 \mathrm{~mL}$ tyrosinase $(250 \mathrm{UI} / \mathrm{mL}), 7.4 \mathrm{~mL}$ phosphate buffer (pH 7) and $0.04 \mathrm{~mL}$ extract were added; then the mixture was incubated 15 minutes at $30^{\circ} \mathrm{C}$. At the end $0.2 \mathrm{~mL} 10 \mathrm{mM} \mathrm{L-DOPA}$ was added. Absorbance was determined at $475 \mathrm{~nm}$ and the ascorbic acid $(340 \mu \mathrm{g} / \mathrm{mL})$ was used as standard $[13,20]$. Acetylcholinesterase inhibition assay. The extract $(1 \mu \mathrm{L})$ was treated with $6 \mathrm{~mL}$ Tris- $\mathrm{HCl}$ buffer $(\mathrm{pH} 8)$ and with $0.05 \mathrm{~mL}$ acetylcholinesterase $(6 \mathrm{UI} / \mathrm{mL})$, then the mixture was incubated 15 minutes at $30^{\circ} \mathrm{C}$. Subsequently, $0.1 \mathrm{~mL}$ 5,5-dithiobis-2-nitrobenzoic acid $(3 \mathrm{mM})$ and $0.1 \mathrm{~mL}$ acetylthiocholine iodide
$(15 \mathrm{mM})$ were added. The hydrolysis of the substrate was monitored by the formation of 5-thio-2-nitrobenzoate anion as the result of the reaction of 5.5-dithiobis-2-nitrobenzoic acid with thiocholine, released by enzymatic hydrolysis of acetyl thiocholine iodide. Absorbance was measured at $405 \mathrm{~nm}$ and galantamine $(1.5 \mathrm{mg} / \mathrm{mL})$ was used as a standard [20, 30, 31].

Trypsin inhibition assay. The assay was based on the spectrophotometric evaluation of trypsin inhibition using bovine serum albumin as a sub-substrate. To $0.1 \mathrm{~mL}$ extract, $0.2 \mathrm{~mL}$ trypsin $(0.05 \%)$ were added and the mixture was incubated at $37^{\circ} \mathrm{C}$, for $20 \mathrm{~min}$. Then, $2 \mathrm{~mL}$ bovine serum albumin $(10 \mathrm{mg} / \mathrm{mL})$ and $4 \mathrm{~mL}$ phosphate buffer ( $\mathrm{pH}$ 7.6) were added. The reaction was stopped by adding $2 \mathrm{~mL}$ trichloroacetic acid $(10 \%)$. The mixture was treated with $1 \mathrm{~mL}$ alkaline cupric reagent and $0.1 \mathrm{~mL}$ phosphomolybdenic reagent. The absorbance was measured at $750 \mathrm{~nm}$. Salicylic acid $(5 \mathrm{mg} / \mathrm{mL})$ was used as standard [12, 16, 21, 29].

Xanthine oxidase inhibition assay. To $0.15 \mathrm{~mL}$ extract, $3.9 \mathrm{~mL}$ phosphate buffer $(\mathrm{pH} 7.4)$ and $0.6 \mathrm{~mL}$ xanthine oxidase $(0.2 \mathrm{UI} / \mathrm{mL})$ were added and then the mixture was incubated 10 minutes at $25^{\circ} \mathrm{C}$. Finally, $4.5 \mathrm{~mL}$ $0.15 \mathrm{mM}$ xanthine was added and this was followed by $30 \mathrm{~min}$ incubation at $25^{\circ} \mathrm{C}$. Allopurinol $(0.3 \mathrm{mg} / \mathrm{mL})$ was used as standard [1, 18, 22].

For all assays the standards and the control samples were prepared in the same manner. The inhibition potency $(\mathrm{I} \%)$ was calculated in all cases with the following formula:

$$
\mathrm{I} \%=\left[1-\mathrm{A}_{\text {sample }} / \mathrm{A}_{\text {control }}\right] \mathrm{x} 100,
$$

where $A_{\text {sample }}$ is the absorbance for sample (with the extract or standard) and $\mathrm{A}_{\text {control }}$ is the absorbance for control (without the extract or standard).

Statistical analysis. The samples were analysed in triplicate; the average and the relative SD were calculated using the Excel software package.

\section{Results and Discussion}

In the Origanum ethanolic extract a high content of total polyphenols $(89.21 \pm 2.79 \mathrm{mg}$ GAE$/ \mathrm{g}$ dry plant material) was determined. The results were similar to those previously obtained $[6,23]$.

With respect to HPLC analysis, Table I and Figure 1 show the phenolic compounds found in the ethanolic extract of $O$. vulgare ssp. vulgare, meaning 8 main phenolic compounds: 5 flavonoids of which 3 glycosides: of quercetin (rutin form), luteolin (glucuronide form) and kaempferol (glucoside form), and 2 free aglycons (luteolin and kaempferol). Rosmarinic acid was found in a large quantity, in accordance with similar results presented by other authors $[6,23,28]$. Two phenolic lactones diterpenes, rosmanol and rosmadial, were determined for the first time in the oregano extract. These antioxidant diterpenic compounds have been also identified in rosemary $[9,27]$. 
HPLC analysis of the phenolic compounds from $O$. vulgare ssp. vulgare

\begin{tabular}{|l|c|c|c|c|}
\hline \multicolumn{1}{|c|}{ Compounds } & $\begin{array}{c}\mathbf{m} / \mathbf{z} \\
\text { value }\end{array}$ & $\begin{array}{c}\mathbf{R}_{\mathbf{t}} \\
(\mathbf{m i n})\end{array}$ & $\begin{array}{c}\text { Peak } \\
\text { No. }\end{array}$ & $\begin{array}{c}\text { Concentration } \\
\text { (mg/g plant product) }\end{array}$ \\
\hline Rutin (quercetin-3-O-rutinoside) & 611 & 15.42 & 1 & $0.67 \pm 0.02$ \\
\hline Luteolin 7- $O$-glucuronide & 463 & 16.03 & 2 & $15.20 \pm 0.70$ \\
\hline Kaempferol-O-glucoside & 448 & 18.07 & 3 & $2.58 \pm 0.42$ \\
\hline Rosmarinic acid & 361 & 18.55 & 4 & $16.89 \pm 0.11$ \\
\hline Rosmanol & 347 & 20.39 & 5 & $1.79 \pm 0.02$ \\
\hline Luteolin & 287 & 21.57 & 6 & $0.55 \pm 0.06$ \\
\hline Rosmadial & 345 & 22.98 & 7 & $0.45 \pm 0.04$ \\
\hline Kaempferol & 287 & 23.49 & 8 & $0.62 \pm 0.08$ \\
\hline
\end{tabular}

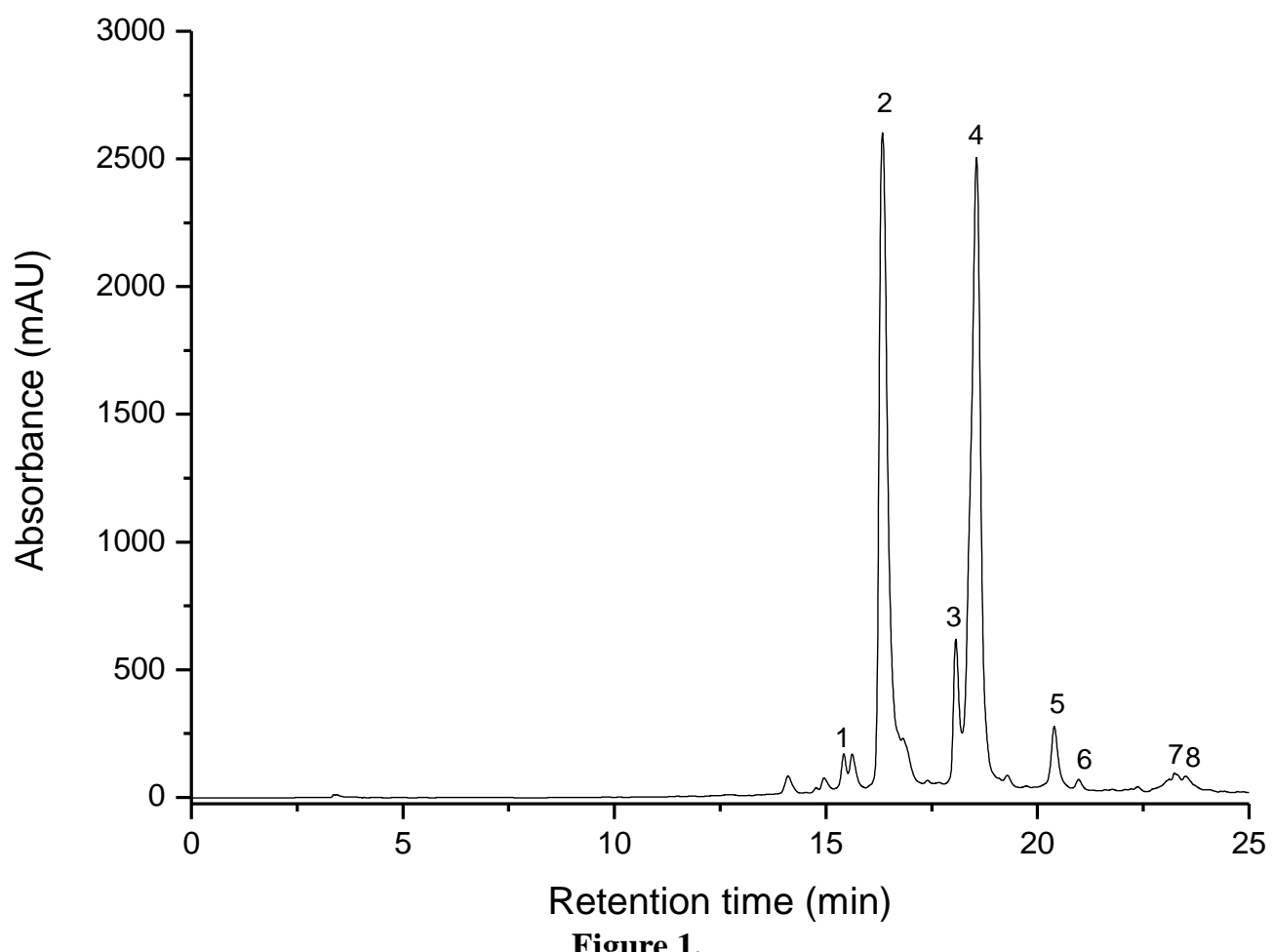

HPLC chromatograms for Origanum vulgare extract

Chromatographic conditions were as given in the Material and Methods section. The identified compounds: 1. Rutin; 2. luteolin 7-O-glucuronide; 3. kaempferol-O-glucoside; 4. rosmarinic acid; 5. Rosmanol; 6. Luteolin; 7. Rosmadial; 8. kaempferol

In order to determine the enzyme inhibitory activity, our extract was tested against urease, tyrosinase, acetylcholinesterase, trypsin and xanthine oxidase (Table II).

There were correlated the total polyphenols content with the individual polyphenols concentrations. The Figure 2 shows that the main identified polyphenols are the rosmarinic acid respectively the luteoline-7-
O-glucuronide, representing 18.9 respectively $17 \%$ from the total polyphenols content, while the others have less than $3 \%$. These polyphenols induce to the $O$. vulgare extract more antioxidant effect, that lead us to foresee mostly an inhibition on oxidative enzymes, like xanthinoxidase or tyrosinase, and less inhibition on hydrolytic enzymes, like acetylcholinesterase or trypsin.

Table II

Enzyme inhibition activity of $O$. vulgare ssp. vulgare extract

\begin{tabular}{|c|c|c|c|c|c|}
\hline \multirow{2}{*}{ Sample } & URE & TYRE & AChE & TRY & XO \\
& inhibition (\%) & inhibition (\%) & inhibition (\%) & inhibition (\%) & inhibitory (\%) \\
\hline O. vulgare extract & $90.47 \pm 6.07$ & $58.63 \pm 8.60$ & $40.67 \pm 3.00$ & $17.1 \pm 0.09$ & $85.19 \pm 5.10$ \\
\hline \multirow{2}{*}{ Standards } & Thi & $\mathrm{Aa}$ & $\mathrm{Ga}$ & $\mathrm{Sa}$ & $\mathrm{Al}$ \\
& $93.26 \pm 5.85$ & $96.53 \pm 5.14$ & $99.83 \pm 1.52$ & $90.2 \pm 0.13$ & $91.05 \pm 2.35$ \\
\hline
\end{tabular}

Each value is the mean \pm SD of three independent measurements. URE: urease; $\alpha$-CHYM: $\alpha$-chymotrypsin; TYRE: tyrosinase; AChE: acetylcholinesterase; TRY: trypsin; XO: xanthine oxidase. Thi: thiourea; Aa: ascorbic acid; Ga: galantamine; Sa: salicylic acid; Al: allopurinol 


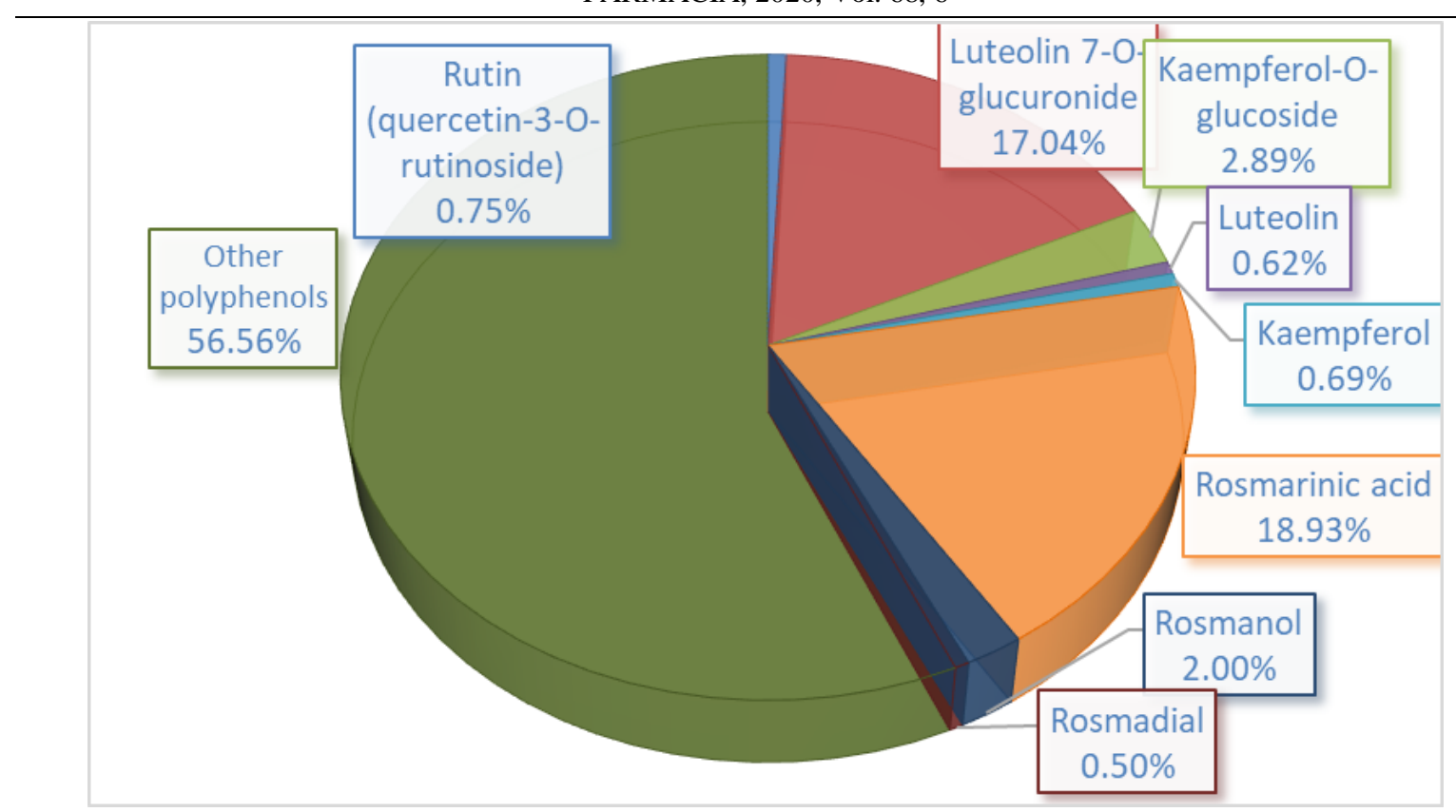

Figure 2.

Percentage distribution of individual polyphenols from total polyphenol content

Data on the enzymatic inhibitory properties of the ethanolic extract obtained from spontaneous $O$. vulgare ssp. vulgare are limited. Our results confirm the foresee upon the phytochemical profile, a better inhibition being obtained on oxidative enzymes, xanthinoxidase and tyrosinase, 85.19 respectively $58.63 \%$.

Urease is a Ni-containing enzyme related to gastroduodenal diseases (gastric and peptic ulcers). It catalyses the hydrolysis of urea to ammonia and carbonic acid, and allows bacteria like Helicobacter pylori to survive at low $\mathrm{pH}$ values of the stomach $[19,24]$. The results of this study suggest that at the tested dose, $O$. vulgare extract revealed a strong in vitro urease inhibitory activity $(90.47 \%)$, very close to inhibition of the standard (Thi: $93.26 \%$ at $200 \mu \mathrm{g} / \mathrm{mL}$ ). So, the oregano extract can be a potential anti-ulcer agent because of the polyphenolic compounds that are involved in the inhibition of Helicobacter pylori [19, 24].

Tyrosinase is an oxidase that converts L-tyrosine to L-DOPA and oxidizes DOPA to dopaquinone, which induces melanin biosynthesis. Tyrosinase inhibitors can control the melanin synthesis and could be useful in therapy (in hyperpigmentation, age spots etc.). In addition, polyphenols structurally similar to DOPA and tyrosine could block the synthesis of melanin. In the same time the lack of dopamine, obtained from LDOPA, is involved in the pathogenesis of Parkinson's disease. Recently the tyrosinase inhibitors were tested to prevent or lower the evolution of this neurodegenerative disease [17]. The tested extract of $O$. vulgare ssp. vulgare showed moderate tyrosinase inhibition activity (58.63\%). Other authors have reported similar anti-tyrosinase activity and rosmarinic acid is probably involved in this effect $[13,15]$.

Cholinesterase inhibition has become the most widely employed clinical approach for treating the symptoms of Alzheimer's disease [31]. In our study, the $O$. vulgare extract had a moderate inhibition activity on AChE (40.67\%). Other authors have achieved comparable results [15].

Trypsin plays an important role in the virulence of many human, plant and insect pathogens. The trypsin inhibitors of plant origin have been reported widely from many plant species. $O$. vulgare extract exhibited low trypsin inhibition activity (17.1\%). Naturally occurring trypsin inhibitors are proteins and this could explain the low activity of the ethanolic extract [12]. A good xanthine oxidase inhibition effect may be associated with a decrease in the production of uric acid. Our extract showed a good xanthine oxidase inhibitory activity (85.19\%), so $O$. vulgare extract can provide encouraging premise for new anti-hyperuricemic natural products [18].

\section{Conclusions}

This study is the first attempt to evaluate the inhibitory action of ethanolic extracts of the indigenous species Origanum vulgare ssp. vulgare on some key enzymes involved in chronic diseases. A specific phenolic profile was highlighted by the presence of rosmarinic acid and luteolin-7-O-glucuronide, as well as rosmanol and rosmadial, two phenolic diterpenes, which are reported for the first time. Our results showed that $O$. vulgare extract revealed a good urease, xanthine oxidase and tyrosinase in vitro inhibitory activity. These preliminary results could be useful for future 
experimental studies, in order to define the efficiency of the $O$. vulgare extract in the treatment of different diseases.

\section{Conflict of interest}

The authors declare no conflict of interest.

\section{References}

1. Alam MN, Bristi NJ, Rafiquzzaman M, Review on in vivo and in vitro methods evaluation of antioxidant activity. Saudi Pharm J., 2013; 21: 143-152.

2. Andriamadio JH, Rasoanaivo LH, Benedec D, Vlase L, Gheldiu AM, Duma M, Toiu A, Raharisololalao A, Oniga I, HPLC/MS analysis of polyphenols, antioxidant and antimicrobial activities of Artabotrys hildebrandtii O. Hffm. extracts. Nat Prod Res., 2015; 29: 2188-96.

3. Badalica-Petrescu M, Dragan S, Ranga F, Fetea F, Socaciu C, Comparative HPLC-DAD-ESI(+)MS Fingerprint and quantification of phenolic and flavonoid composition of aqueous leaf extracts of Cornus mas and Crataegus monogyna, in relation to their cardiotonic potential. Not Bot Horti Agrobo., 2014; 42: 9-18.

4. Benedec D, Danganu D, Filip L, Oniga I, Tiperciuc B, Olah NK, Gheldiu AM, Raita O, Vlase L, Chemical, antioxidant and antibacterial studies of Romanian Heracleum sphondylium. Farmacia, 2017; 65(2): 253-256.

5. Benedec D, Hanganu D, Oniga I, Filip L, Bischin C, Silaghi R, Tiperciuc B, Vlase L, Achillea schurii flowers: chemical, antioxidant and antimicrobial investigations. Molecules, 2016; 21(8): 1-12.

6. Benedec D, Hanganu D, Oniga I, Tiperciuc B, Olah N, Raita O, Bischin C, Silaghi R, Vlase L, Assessment of rosmarinic acid content in six Lamiaceae species extracts and their antioxidant and antimicrobial potential. Pak J Pharm Sci., 2015; 28: 2297-2303.

7. Benedec D, Oniga I, Cuibus F, Sevastre B, Stiufiuc G, Duma M, Hanganu D, Iacovita C, Stiufiuc R, Lucaciu $\mathrm{CM}$, Origanum vulgare mediated green synthesis of biocompatible gold nanoparticles simultaneously possessing plasmonic, antioxidant and antimicrobial properties. Int J Nanomedicine, 2018; 13: 1041-1058.

8. Benedec D, Oniga I, Kozma-Imre A, Hanganu D, Ţărmure V, Bodoki E, Determination of rosmarinic acid by HPTLC-image analysis in medicinal teas and their biological properties. Farmacia, 2017; 65(4): 605-609.

9. Bunghez F, Rotar MA, Pop RM, Romanciuc F, Csernatoni F, Fetea F, Diaconeasa Z, Socaciu C, Comparative phenolic fingerprint and LC-ESI+QTOFMS composition of oregano and rosemary hydrophilic extracts in relation to their antibacterial effect. Bull UASVM Food Sci Technol., 2015; 72: 33-40.

10. Chishti S, Kaloo ZA, Sultan PJ, Medicinal importance of genus Origanum: a review. Pharmacognosy Phytother., 2013; 5: 170 -177.

11. Chishti S, Sultan P, Kaloo ZA, Wani BA, Sheikh MA, Antibacterial activity and DPPH scavenging antioxidant potential in Origanum vulgare L. Int $J$ Adv Res Biol Sci., 2014; 1: 15-21.

12. Divya C, Sreejina Sreedharan K, Punathum Parambath $\mathrm{B}$, Meethal V, Identification of plant extracts expressing trypsin inhibitor. Acta Biologica Indica, 2014; 3: 522-526.

13. Doveci E, Tel-Cavan G, Duru ME, Phenolic profile, antioxidant, anticholinesterase, and anti-tyrosinase activities of the various extracts of Ferula elaeochytris and Sideritis stricta. Int J Food Prop., 2018; 21: 771-783.

14. Epure A, Oniga I, Benedec D, Hanganu D, Gheldiu AM, Toiu A, Vlase L, Chemical analysis and antioxidant activity of some rooibos tea products. Farmacia, 2019; 67(6): 963-966.

15. Gonçalves S, Moreira E, Grosso C, Paula BA, Valentão $\mathrm{P}$, Romano A, Phenolic profile, antioxidant activity and enzyme inhibitory activities of extracts from aromatic plants used in Mediterranean diet. J Food Sci Technol., 2017; 54: 219-227.

16. Hade S, Joshi P, Pilley H, Wadegaonkar V, Wadegaonkar $\mathrm{P}$, Evaluation of Crataeva nurvala extracts as antioxidant, antiproteolytic and cytotoxic against hepato-carcinoma and mouse melanoma cell line. $J$ Appl Pharm Sci., 2016; 6: 189-196.

17. Hasegawa $T$, Tyrosinase-expressing neuronal cell line as in vitro model of parkinson's disease. Int $\mathrm{J} \mathrm{Mol}$ Sci., 2010; 11: 1082-1089.

18. Hudaib MM, Tawaha KA, Mohammad MK, Assaf AM, Issa AY, Alali FQ, Aburjai TA, Bustanji YK. Xanthine oxidase inhibitory activity of the methanolic extracts of selected Jordanian medicinal plants. Pharmacogn Mag., 2011; 7: 320-324.

19. Lin YT, Kwon YI, Labbe RG, Shetty K, Inhibition of Helicobacter pylori and associated urease by oregano and cranberry phytochemical synergies. Appl Environ Microbiol., 2005; 71: 8558-64.

20. Neagu E, Paun G, Albu C, Radu GL, Assessment of acetylcholinesterase and tyrosinase inhibitory and antioxidant activity of Alchemilla vulgaris and Filipendula ulmaria extracts. J Taiwan Inst Chem Eng., 2015; 52: 1-6.

21. Nile SH, Park SW, Optimized methods for in vitro and in vivo anti-inflammatory assays and its applications in herbal and synthetic drug analysis. Mini-Rev Med Chem., 2013; 13: 95-100.

22. Noro T, Oda Y, Miyase T, Ueno A, Fukushima S, Inhibitors of xanthine oxidase from the flowers and buds of Daphne genkwa. Chem Pharm Bull., 1983; 31: 3984-3987.

23. Oniga I, Pușcaș C, Silaghi-Dumitrescu R, Olah NK, Sevastre B, Marica R, Marcus I, Sevastre-Berghian AC, Benedec D, Pop CE, Hanganu D, Origanum vulgare ssp. vulgare: Chemical composition and biological studies. Molecules, 2018; 23(8): 1-14.

24. Paun G, Litescu SC, Neagu E, Tache A, Radu GL, Evaluation of Geranium spp., Helleborus spp. and Hyssopus spp. polyphenolic extracts inhibitory activity against urease and $\alpha$-chymotrypsin. $J$ Enzyme Inhib Med Chem., 2014; 29: 28-34.

25. Păduraru DN, Coman F, Ozon EA, Gherghiceanu F, Andronic O, Ion D, Stănescu M, Bolocan A, The use of nutritional supplement in Romanian patients Attitudes and beliefs. Farmacia, 2019; 67(6): 10601065.

26. Pezzani R, Vitalini S, Iriti M, Bioactivities of Origanum vulgare L.: an update. Phytochem Rev., 2017; 16: 1253-1268. 
27. Razboršek MI, Vončina DB, Doleček V, Voncina E, Determination of major phenolic acids, phenolic diterpenes and triterpenes in rosemary (Rosmarinus officinalis L.) by gas chromatography and mass spectrometry. Acta Chim Slov., 2007; 54: 60-67.

28. Shekarchi M, Hajimehdipoor H, Saeidnia S, Gohari AR, Hamedani MP, Comparative study of rosmarinic acid content in some plants of Labiatae family. Pharmacogn Mag., 2012; 8: 37-41.

29. Tandon M, Tandon P, Barthwal J, Bhalla TN, Bhargava $\mathrm{KP}$, Anti-inflammatory and antiproteolytic activities of newer indolyl isoquinolones. Drug Res., 1982; 32: 1233-1235.
30. Topcu G, Kusman T, Lamiaceae Family plants as a potential anticholinesterase source in the treatment of Alzheimer's disease. Bezmialem Science, 2014; 1: $1-25$.

31. Vladimir-Knežević S, Blažeković B, Kind M, Vladić J, Lower-Nedza AD, Brantner AH, Acetylcholinesterase inhibitory, antioxidant and phytochemical properties of selected medicinal plants of the Lamiaceae family. Molecules, 2014; 19: 767-782.

32. $\mathrm{xxx}$ - European Pharmacopoeia, $8^{\text {th }}$ edition, Council of Europe, 2014. 